\title{
TINGKAT KESIAPAN PESERTA DIDIK KOMPETENSI KEAHLIAN DESAIN PEMODELAN DAN INFORMASI BANGUNAN DALAM MENGHADAPI DUNIA KERJA (Studi di SMK Negeri 2 Garut)
}

\author{
Hanna Siti Anisa ${ }^{1}$, Nandan Supriatna ${ }^{2}$ dan Dedi Purwanto ${ }^{3}$ \\ 1,2,3 Pendidikan Teknik Bangunan, FPTK, UPI \\ Email: hannasitianisa@gmail.com
}

\begin{abstract}
ABSTRAK
Peserta didik SMK diprogram oleh pemerintah untuk bisa terjun ke dunia kerja/ dunia industri setelah lulus dan selesai dari masa studinya. Kerja merupakan pencapaian yang dilakukan untuk menerapkan antara pengetahuan teori dan praktek yang diperoleh di sekolah dan dunia industri. Pengalaman bekerja merupakan salah satu aspek tingkat kesiapan dari peserta didik yang didapat dari dunia industri ketika melaksanakan praktek kerja lapangan. Tingkat kesiapan peserta didik yang beragam merupakan salah satu hal yang bisa menjadi tolak ukur ketika para peserta didik lulus dari sekolah. Maka dari itu tujuan dari penelitian ini yaitu untuk mengetahui tingkat kesiapan kerja dari peserta didik kompetensi keahlian desain pemodelan dan informasi bangunan. Instrumen yang digunakan pada penelitian ini yaitu kuisioner/angket dengan metode analisis data yang digunakan yaitu metode deskriptif dan pendekatan kuantitatif dengan presentase. Responden pada penelitian difokuskan kepada para peserta didik kompetensi keahlian desain pemodelan dan informasi bangunan SMK Negeri 2 Garut yang telah melaksanakan praktek kerja lapangan dengan pengumpulan data menggunakan metode angket tertutup. Hasil penelitian yang didapat berdasarkan aspek-aspek tingkat kesiapan kerja yang digunakan pada penelitian ini menunjukkan $8 \%$ peserta didik sangat siap, 55\% peserta didik siap, 27\% peserta didik menyatakan tidak siap dan $10 \%$ peserta didik sangat tidak siap. Berdasarkan hasil tersebut tingkat kesiapan kerja peserta didik ada di kategori baik dan cukup siap untuk menghadapi dunia kerja.
\end{abstract}

Kata kunci: Tingkat Kesiapan, Peserta Didik SMK, Dunia Kerja

\section{ABSTRACT}

Vocational High School students are programmed by the government to be able to enter the world of work/industrial world after graduating and completing their studies. Work is an achievement made to apply the theoretical and practical knowledge acquired in school and industry. Work experience is one aspect of the readiness level of students obtained from the industrial world when carrying out field work practices. The level of readiness of students who are diverse is one thing that can be used as a benchmark when students graduate from school. Therefore, the purpose of this study is to determine the level of work readiness of students with competency in modeling design skills and building information. The instrument used in this study is a questionnaire/questionnaire with data analysis methods used, namely descriptive methods and quantitative approaches with percentages. Respondents in the study focused on the students' competence in modeling and building information design skills at SMK Negeri 2 Garut who had carried out field work practices by collecting data using a closed questionnaire method. The results obtained based on the aspects of the level of work readiness used in this study showed $8 \%$ of students were very ready, 55\% of students were ready, 27\% of students said they were not ready and $10 \%$ of students were much unprepared. Based on these results, the level of work readiness of students is in the good category and quite ready to face the world of work.

Keywords: Level of Readiness, Vocational School Students, World of Work

\section{PENDAHULUAN}

Pendidikan memegang peranan
penting dalam meningkatkan kualitas
sumber daya manusia Indonesia yang
diperlukan di era globalisasi ini. Pendidikan adalah usaha untuk mengembangkan potensi yang dimiliki oleh peserta didik melalui proses bimbingan, pengajaran dan pelatihan. Proses pendidikan merupakan suatu sistem yang terdiri dari input, proses dan output. Input merupakan kegiatan dari belajar 
mengajar sedangkan output merupakan hasil dari proses pembelajaran yang telah dilaksanakan. Dari pelaksanaan proses pendidikan tersebut diharapkan dapat menghasilkan sumber daya manusia yang berkualitas, bermutu dan berdaya saing tinggi untuk menghadapi persaingan di era globalisasi.

Pendidikan Nasional berfungsi mengembangkan kemampuan dan membentuk watak serta peradaban bangsa yang bermartabat dalam rangka mencerdasakan kehidupan bangsa, bertujuan untuk berkembangnya potensi peserta didik agar menjadi manusia yang beriman dan bertakwa kepada Tuhan Yang Maha Esa, berakhlak mulia, sehat, berilmu, cakap, kreatif, mandiri dan menjdi warga negara yang demokratis serta bertanggung jawab (Pasal 3 UU RI No. 20/2003).

Jenis dari pendidikan menengah salah satunya adalah Sekolah Menengah Kejuruan (SMK), yang mengacu pada undang-undang mengenai tujuan pendidikan nasional dan dij elaskan dalam UUSPN Pasal 15 Departemen Pendidikan Nasional (2006, hlm.8) menyebutkan bahwa "pendidikan kejuruan merupakan pendidikan menengah yang bertujuan mempersiapkan peserta didik terutama untuk dapat bekerja dalam bidang tertentu". SMK Negeri 2 Garut merupakan salah satu dari sekolah menengah kejuruan yang berada di Indonesia khususnya di wilayah Jawa Barat yang memiliki berbagai macam kompetensi keahlian. Diantara berbagai kompetensi keahlian tersebut terdapat kompetensi keahlian Desain Pemodelan dan Informasi Bangunan (DPIB), yang mana lulusan dari Kompetensi Keahlian ini diharapkan kompeten dalam menggambar dan mendesain bangunan/gedung serta menguasai konsepkonsep tentang bangunan.
Dalam upaya mencapai lulusan yang diharapkan tadi, SMK Negeri 2 Garut khususnya jurusan Desain Pemodelan dan Informasi Bangunan berupaya dengan meningkatkan kompetensi peserta didiknya melalui kegiatan Praktek Kerja Lapangan (PKL). Proses kegiatan tersebut sebagai sarana penerapan, pemantapan dan peningkatan kompetensi sesuai dengan bidang keahlian dan tuntutan kerja di lapangan. PKL merupakan salah satu kegiatan wajib bagi peserta didik SMK dimana kegiatan belajar yang berorientasi langsung di Dunia Usaha/Dunia Industri. Peserta didik kompetensi keahlian DPIB yang melaksanakan kegiatan PKL ditempatkan pada bagian drafter akan tetapi saat di lapangan pada bagian lain pun seperti pengawas maupun juru ukur tetap diisi sesuai kebutuhan dari pihak kontraktor maupun konsultan. Dalam Kurikulum 2013 (revisi 2017) kegiatan PKL tersebut dilaksanakan selama 120 hari/ 24 minggu/ 6 bulan. Pelaksanaan Praktek Kerja Lapangan (PKL) di Kompetensi Keahlian Desain Pemodelan dan Informasi Bangunan SMK Negeri 2 Garut pada tahun pelajaran 20172018 yaitu pada tingkat XI semester genap, tepatnya dari Bulan Januari sampai dengan Bulan April.

Berbeda dengan pelaksanaan PKL pada tahun-tahun sebelumnya yang dilaksanakan pada kelas XII, setelah penulis melakukan obeservasi terdapat berbagai faktor yang mempengaruhi tingkat kesiapan peserta didik dalam menghadapi dunia kerja dengan terlaksananya kegiatan PKL lebih awal. Menurut Nurhaniah (2013, hlm 3) kesiapan kerja peserta didik SMKN Jurusan Bangunan di Kabupaten Sleman termasuk dalam kategori sangat tinggi dengan nilai rerata sebesar 83,61. Prestasi belajar dan pengetahuan tentang dunia kerja memiliki 
peranan yang signifikan terhadap kesiapan kerja. Dari hasil penelitian tersebut prestasi belajar merupakan kategori kesiapan kerja berupa hard skill yang memang dapat diukur kepada peserta didik. Faktor-faktor lain yang mempengaruhi kesiapan kerja belum dibahas pada penelitian tersebut. Berdasarkan uraian diatas, menjadikan latar belakang judul yang diambil oleh penulis, yaitu "Tingkat Kesiapan Peserta Didik Kompetensi Keahlian Desain Pemodelan dan Informasi Bangunan SMK Negeri 2 Garut Dalam Menghadapi Dunia Kerja”.

\section{METODE}

Penelitian ini merupakan penelitian berupa survei. Populasi dalam penelitian ini yaitu seluruh peserta didik kelas XII kompetensi keahlian desain pemodelan dan informasi bangunan SMK Negeri 2 Garut yang telah melaksanakan Praktek Kerja Lapangan (PKL) pada semester sebelumnya. Pengambilan sampel dengan metode random sampling dan dibatasi sebanyak 20 responden dari keseluruhan populasi.

Instrumen pengumpulan data berupa kuisioner/angket dengan didukung data hasil observasi dan dokumentasi. Angket yang digunakan merupakan angket tertutup yang disusun dalam rangka mengungkap berbagai hal yang telah dilaksanakan daan didapat oleh responden dan kondisi yang terjadi pada saat ini. Tanggapan dari responden yang ingin diungkap yakni terkait dengan tingkat kesiapan peserta didik dalam menghadapi dunia kerja berdasarkan soft skill yang telah dimiliki setelah pelaksanaan Praktek Kerja Lapangan (PKL). Metode dokumentasi digunakan untuk memperkuat hasil penelitian yang didapat, nilai peseta didik menunjang tingkat kesiapan yang dimiliki. Analisis data dilakukan dengan teknik statistik deskriptif melalui pendekatan kuantitatif.

\section{HASIL DAN PEMBAHASAN}

Data yang didapat dari hasil penelitian dibahas dengan cara mendeskripsikan bagaimana tingkat kesiapan kerja para peserta didik yang mengacu dari telah terlaksananya praktik kerja lapangan pada semester sebelumnya. Pengumpulan data melalui metode angket, peneliti melakukan dua kali penyebaran angket. Pertama, angket uji coba yang disebar dilakukan kepada 20 responden dengan 46 item soal. Pada uji coba tersebut terdapat 9 item soal yang tidak valid sehingga item yang valid berjumlah 37 soal. Angket yang kedua dengan 37 item soal merupakan angket yang sudah valid dan disebarkan kepada 74 responden.

Pengolahan data dari hasil angket penelitian secara keseluruhan didapat berdasarkan skor seluruh soal yang ada dan di urutkan sesuai hasil dari nilai yang telah dicapai. Dari jumlah pernyataan pada angket sebanyak 37 item soal, peserta didik telah mengisi sesuai dengan keadaan dan kesadaran diri mereka masing-masing. Soalsoal pada angket penelitian tersebut telah diisi oleh 74 responden yang berasal dari kelas XII DPIB 1, XII DPIB 2 dan XII DPIB 3 SMK Negeri 2 Garut dan dijabarkan melalui deskripri statistik, kategori penilaian dan diagram pie yang dipaparkan sebagai berikut:

Tabel 1. Deskripsi Statistik Tingkat Kesiapan Peserta Didik Dalam Menghadapi Dunia Kerja

\begin{tabular}{lc}
\hline \multicolumn{1}{c}{ Statistik } & Skor \\
\hline Skor ideal & 148 \\
Mean (rata-rata) & 129,5 \\
Median (nilai tengah) & 132 \\
Mode (modus) & 135 \\
Standard Deviation (standar & 7 \\
deviasi) &
\end{tabular}




\begin{tabular}{lc}
\hline \multicolumn{1}{c}{ Statistik } & Skor \\
\hline Minimun (nilai terendah) & 110 \\
Maximum (nilai tertinggi) & 145 \\
\hline
\end{tabular}

Berdasarkan tabel 1 diketahui rata-rata tingkat kesiapan peserta didik kompetensi keahlian desain pemodelan dan informasi bangunan SMK Negeri 2 Garut dalam menghadapi dunia kerja sebesar 129,5 atau jika dibulatkan keatas sebesar 130 yang menunjukan nilai rerata (mean) dari kelompok data keseluruhan pengukuran. Standar deviasi sebesar 7 menunjukan simpangan kuadrat dari nilai tengah yang didapat dari sebaran kelompok data. Nilai terendah yang diperoleh sebesar 110 dan nilai tertinggi yang diperoleh sebesar 145 dengan skor ideal 148.

Tabel 2. Kategori Penilaian Tingkat Kesiapan Peserta Didik Dalam Menghadapi Dunia Kerja

\begin{tabular}{|c|c|c|c|c|}
\hline No & Interval & Kategori & Frekuensi & Presentase \\
\hline 1 & $X \geq 140$ & $\begin{array}{l}\text { Sangat } \\
\text { Siap }\end{array}$ & 6 & $8 \%$ \\
\hline 2 & $\begin{array}{l}129,5 \leq \\
X<140 \\
119<X\end{array}$ & $\begin{array}{l}\text { Siap } \\
\text { Tidak }\end{array}$ & 41 & $55 \%$ \\
\hline 3 & $<129,5$ & $\begin{array}{c}\text { Siap } \\
\text { Sangat }\end{array}$ & 20 & $27 \%$ \\
\hline 4 & $X<119$ & $\begin{array}{l}\text { Tidak } \\
\text { Siap }\end{array}$ & 7 & $10 \%$ \\
\hline \multicolumn{3}{|c|}{ Jumlah } & 74 & $100 \%$ \\
\hline
\end{tabular}

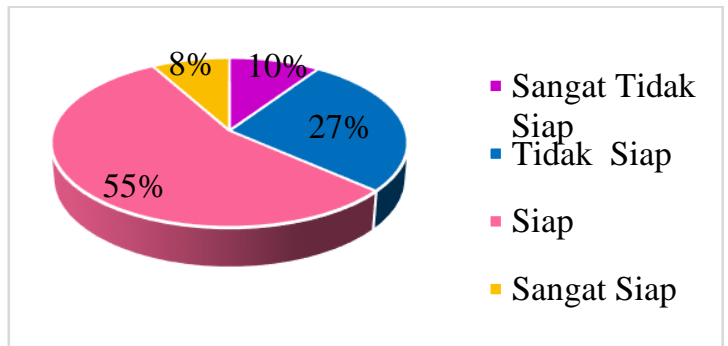

Gambar 1. Presentase Tingkat Kesiapan Peserta Didik Dalam Menghadapi Dunia Kerja

Berdasarkan tabel dan diagram diatas, dapat dilihat bahwa tingkat kesiapan peserta didik kompetensi keahlian desain pemodelan dan informasi bangunan SMK Negeri 2 Garut dalam menghadapi dunia kerja secara umum berada pada kategori siap, dengan presentase kesiapan sebesar $55 \%$.

Hasil skor rata-rata (mean) tingkat kesiapan peserta didik kompetensi keahlian desain pemodelan dan informasi bangunan sebesar $129,5 \approx 130$ skor ini berada pada skala interval 130-139 yang menunjukan bahwa tingkat kesiapan kerja peserta didik berada pada kategori siap. Menurut Ketua Program Jurusan DPIB SMK Negeri 2 Garut para peserta didik memang dipersiapkan untuk mampu menghadapi persaingan di dunia kerja karena sesuai pada hakikatnya lulusan dari SMK di persiapkan untuk bekerja di bidang konstruksi.

Jika dilihat secara keseluruhan dari berbagai aspek atau faktor-faktor tingkat kesiapan diantaranya yaitu tingkat kematangan, memiliki pengalaman bekerja, memiliki sikap kritis, dapat berkomunikasi, memiliki kesehatan fisik dan mental, bertanggung jawab dan mampu beradaptasi berikut penulis paparkan hasil dari tiap aspek secara detail.

\section{Aspek Tingkat Kematangan}

Dari hasil penelitian yang telah dilakukan menunjukkan bahwa peserta didik yang akan menghadapi dunia kerja dapat dikategorikan memiliki kesiapan yang baik. Deskripsi data hasil penelitian menujukkan nilai sebesar 5\% untuk jawaban sangat siap, $54 \%$ untuk pernyataan siap, $34 \%$ menyatakan tidak siap dan $7 \%$ menyatakan sangat tidak siap. Dari hasil analisis data hal ini menunjukan bahwa aspek ini berpengaruh tinggi. Tingkat kematangan disebabkan oleh berbagai faktor diantaranya kondisi fisik dan emosional peserta didik yang semakin bertambah dan menyebabkan perubahan tingkah laku. Perubahan tingkah laku didasarkan pada pertumbuhan dan 
perkembangan setiap individu dari hari ke hari dengan adanya interaksi.

Tabel 3. Deskripsi Statistik Aspek Tingkat Kematangan

\begin{tabular}{lc}
\hline \multicolumn{1}{c}{ Statistik } & Skor \\
\hline Skor ideal & 36 \\
Mean (rata-rata) & 31,8 \\
Median (nilai tengah) & 32 \\
Mode (modus) & 33 \\
Standard Deviation (standar deviasi) & 1,8 \\
Minimun (nilai terendah) & 27 \\
Maximum (nilai tertinggi) & 36 \\
\hline
\end{tabular}

Tabel 4. Kategori Penilaian Aspek Tingkat Kematangan

\begin{tabular}{|c|c|c|c|c|}
\hline No & Interval & Kategori & Frekuensi & Presentase \\
\hline 1 & $X \geq 34,5$ & $\begin{array}{l}\text { Sangat } \\
\text { Siap }\end{array}$ & 6 & $5 \%$ \\
\hline 2 & $\begin{array}{c}31,8 \leq X \\
<34,5\end{array}$ & Siap & 40 & $54 \%$ \\
\hline 3 & $\begin{array}{c}29 \leq \mathrm{X}< \\
31,8\end{array}$ & $\begin{array}{c}\text { Tidak } \\
\text { Siap } \\
\text { Sangat }\end{array}$ & 25 & $34 \%$ \\
\hline 4 & $X<29$ & $\begin{array}{l}\text { Tidak } \\
\text { Siap }\end{array}$ & 7 & $7 \%$ \\
\hline \multicolumn{3}{|c|}{ Jumlah } & 74 & $100 \%$ \\
\hline
\end{tabular}

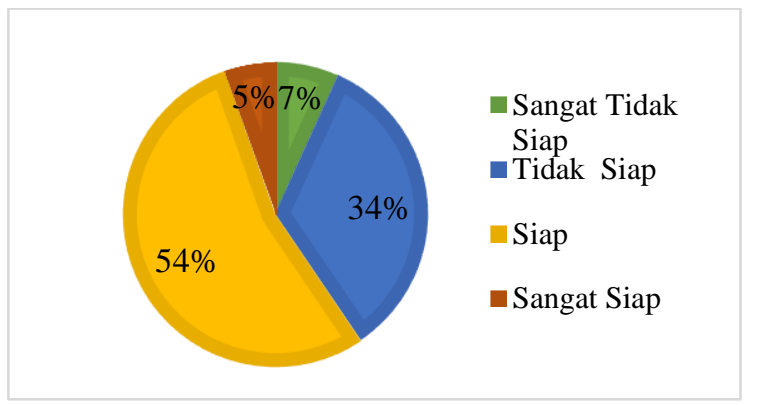

Gambar 2. Presentase Kesiapan Aspek Tingkat Kematangan

\section{Aspek Memiliki Pengalaman Bekerja}

Hasil penelitian menunjukkan bahwa pada faktor ini peseta didik yang menjawab sangat siap sebesar $0 \%$, yang menyatakan siap sebanyak $62 \%$, lalu $31 \%$ menyatakan tidak siap dan $7 \%$ menyatakan sangat tidak siap. Dari hasil analisis data hal ini dikarenakan pengalaman memiliki efek kumulatif dalam perkembangan fungsi kepribadian setiap individu. Karena peserta didik yang diteliti telah melaksanakan praktek kerja lapangan pada semester sebelumnya, sehingga pengalaman akan dunia kerja masih melekat pada diri masingmasing peserta didik dan aspek ini cukup berpengaruh tinggi.

Tabel 5. Deskripsi Statistik Aspek Memiliki Pengalaman Bekerja

\begin{tabular}{lc}
\hline \multicolumn{1}{c}{ Statistik } & Skor \\
\hline Skor ideal & 12 \\
Mean (rata-rata) & 10,5 \\
Median (nilai tengah) & 11 \\
Mode (modus) & 11 \\
Standard Deviation (standar deviasi) & 1,2 \\
Minimun (nilai terendah) & 6 \\
Maximum (nilai tertinggi) & 12 \\
\hline
\end{tabular}

Tabel 6. Kategori Penilaian Aspek Tingkat Kematangan

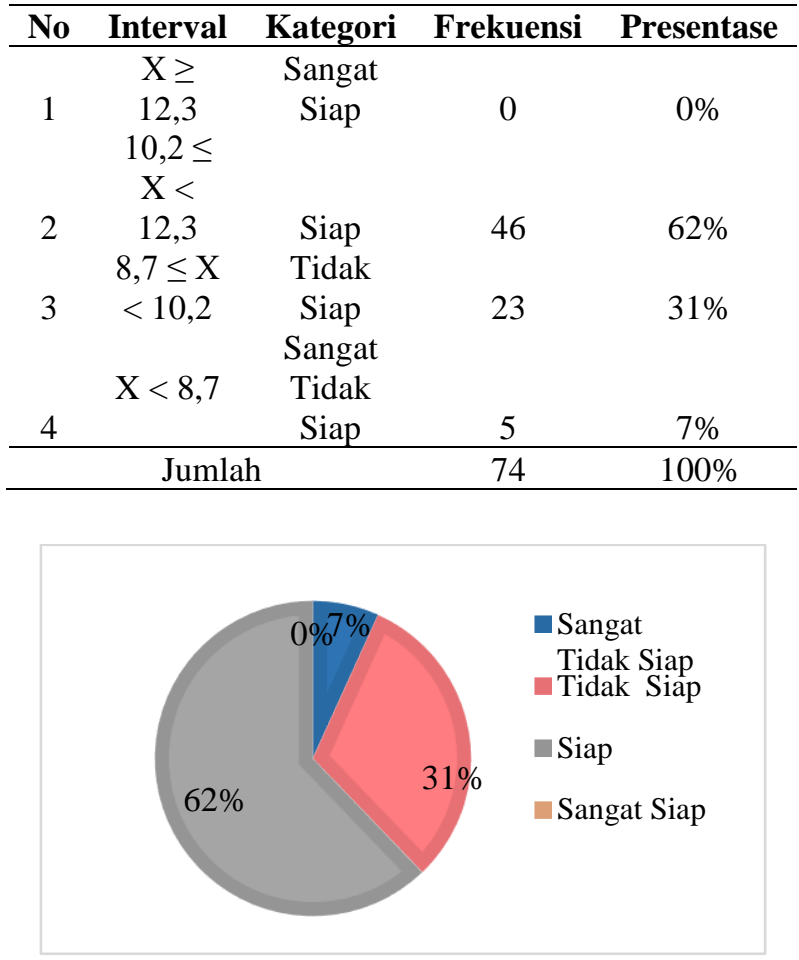

Gambar 3. Presentase Aspek Memiliki Pengalaman Bekerja

\section{Aspek Memiliki Sikap Kritis}

Dari hasil penelitian untuk aspek memiliki pemikiran kritis hasil dari peserta didik didapat $1 \%$ menyatakan sangat siap, $49 \%$ menyatakan siap, $42 \%$ lainnya menjawab tidak siap dan $8 \%$ menyatakan 
sangat tidak siap. Untuk bisa bekerja di bidang konstruksi peserta didik di tuntut memiliki pemikiran kritis yang mengandalkan logika dan kekuatan berfikir yang cepat dan tepat dalam menghadapi situasi dan kondisi di dunia kerja.

Tabel 7. Deskripsi Statistik Aspek Memiliki Sikap Kritis

\begin{tabular}{lc}
\hline \multicolumn{1}{c}{ Statistik } & Skor \\
\hline Skor ideal & 24 \\
Mean (rata-rata) & 20,5 \\
Median (nilai tengah) & 20,5 \\
Mode (modus) & 22 \\
Standard Deviation (standar deviasi) & 1,8 \\
Minimun (nilai terendah) & 15 \\
Maximum (nilai tertinggi) & 24 \\
\hline
\end{tabular}

Tabel 8. Kategori Penilaian Aspek Memiliki Sikap Kritis

\begin{tabular}{|c|c|c|c|c|}
\hline No & Interval & Kategori & Frekuensi & Presentase \\
\hline 1 & $\begin{array}{c}X \geq \\
23,2 \\
20,5 \leq \\
X<\end{array}$ & $\begin{array}{c}\text { Sangat } \\
\text { Siap }\end{array}$ & 1 & $1 \%$ \\
\hline 2 & $\begin{array}{c}23,2 \\
17,8 \leq\end{array}$ & Siap & 36 & $49 \%$ \\
\hline 3 & $\begin{array}{l}X< \\
20,5 \\
V<\end{array}$ & $\begin{array}{c}\text { Tidak } \\
\text { Siap } \\
\text { Sangat }\end{array}$ & 31 & $42 \%$ \\
\hline 4 & 17,8 & $\begin{array}{c}\text { Tidak } \\
\text { Siap }\end{array}$ & 6 & $8 \%$ \\
\hline & Jum & & 74 & $100 \%$ \\
\hline
\end{tabular}

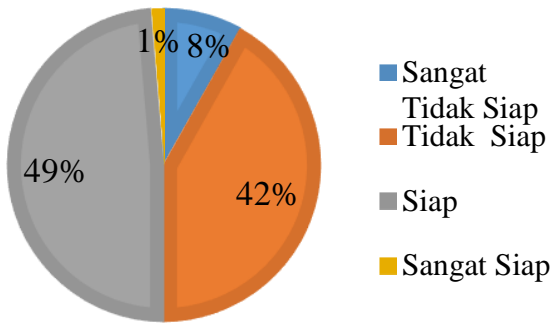

Gambar 4. Presentase Aspek Memiliki Sikap Kritis

\section{Aspek Dapat Berkomunikasi}

Tingkat kesiapan kerja berdasarkan kemampuan peserta didik berkomunikasi, hal ini mendapat nilai sangat siap sebanyak $7 \%$, menyatakan siap sebanyak $51 \%$, dengan perolehan tidak siap sebanyak $35 \%$ dan sangat tidak siap sebanyak 7\%. Dari hasil temuan pada pernyataan-pernyataan ini kemampuan berkomunikasi para peserta didik sudah bisa dikatakan baik untuk dapat menunjang kesiapan mereka di dunia kerja.

Tabel 9. Deskripsi Statistik Aspek Dapat Berkomunikasi

\begin{tabular}{lc}
\hline \multicolumn{1}{c}{ Statistik } & Skor \\
\hline Skor ideal & 28 \\
Mean (rata-rata) & 24,7 \\
Median (nilai tengah) & 25 \\
Mode (modus) & 25 \\
Standard Deviation (standar deviasi) & 1,8 \\
Minimun (nilai terendah) & 19 \\
Maximum (nilai tertinggi) & 28 \\
\hline
\end{tabular}

Tabel 10. Kategori Penilaian Aspek Dapat Berkomunikasi

\begin{tabular}{|c|c|c|c|c|}
\hline No & Interval & Kategori & Frekuensi & Presentase \\
\hline & $X \geq$ & Sangat & & \\
\hline 1 & $\begin{array}{c}27,4 \\
24,7 \leq \\
X<\end{array}$ & Siap & 5 & $7 \%$ \\
\hline 2 & $\begin{array}{c}27,4 \\
22 \leq X\end{array}$ & $\begin{array}{l}\text { Siap } \\
\text { Tidak }\end{array}$ & 38 & $51 \%$ \\
\hline 3 & $<24,7$ & $\begin{array}{c}\text { Siap } \\
\text { Sangat }\end{array}$ & 26 & $35 \%$ \\
\hline 4 & $x<22$ & $\begin{array}{l}\text { Tidak } \\
\text { Siap }\end{array}$ & 5 & $7 \%$ \\
\hline \multicolumn{3}{|c|}{ Jumlah } & 74 & $100 \%$ \\
\hline
\end{tabular}

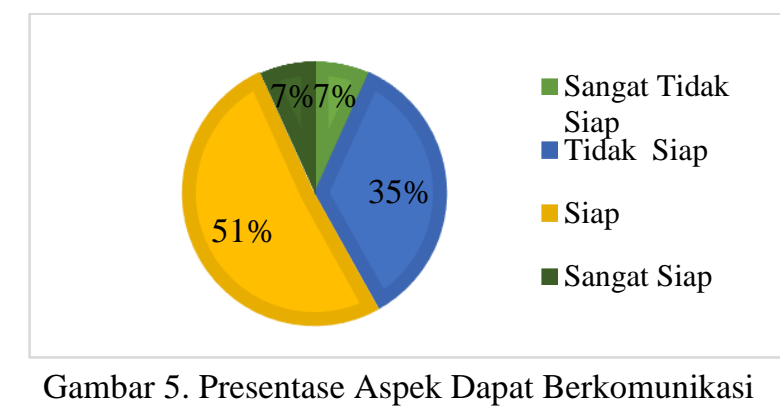

\section{Aspek Kesehatan Fisik dan Mental}

Berdasarkan hasil penelitian yang di dapat aspek kesehatan fisik dan mental mendapat hasil $0 \%$ sangat siap, $49 \%$ menjawab siap, 39\% menyatakan tidak siap dan $12 \%$ sangat tidak siap yang menandakan bahwa peserta didik memang sudah siap baik secara fisik maupun mental. Besarnya 
presentase tingkat kesiapan yang diperoleh dari responden menandakan keadaan jasmani dan rohani seseorang dikatakan siap yang artinya telah mampu melakukan sesuatu yang dikehendaki tanpa kesulitan.

Tabel 11. Deskripsi Statistik Kesehatan Fisik dan Mental

\begin{tabular}{lc}
\hline \multicolumn{1}{c}{ Statistik } & Skor \\
\hline Skor ideal & 16 \\
Mean (rata-rata) & 14,2 \\
Median (nilai tengah) & 14 \\
Mode (modus) & 15 \\
Standard Deviation (standar deviasi) & 1,34 \\
Minimun (nilai terendah) & 11 \\
Maximum (nilai tertinggi) & 16 \\
\hline
\end{tabular}

Tabel 12. Kategori Penilaian Aspek Kesehatan Fisik dan Mental

\begin{tabular}{|c|c|c|c|c|}
\hline No & Interval & Kategori & Frekuensi & Presentase \\
\hline & $X \geq$ & Sangat & & \\
\hline 1 & $\begin{array}{c}16,2 \\
14,2 \leq\end{array}$ & Siap & 0 & $0 \%$ \\
\hline 2 & $\begin{array}{c}X< \\
16,2 \\
12,3 \leq\end{array}$ & Siap & 38 & $49 \%$ \\
\hline 3 & $\begin{array}{l}X< \\
14,2\end{array}$ & $\begin{array}{l}\text { Tidak } \\
\text { Siap }\end{array}$ & 29 & $39 \%$ \\
\hline 4 & $\begin{array}{l}X< \\
12,3\end{array}$ & $\begin{array}{l}\text { Sangat } \\
\text { Tidak } \\
\text { Siap }\end{array}$ & 9 & $12 \%$ \\
\hline \multicolumn{3}{|c|}{ Jumlah } & 74 & $100 \%$ \\
\hline
\end{tabular}

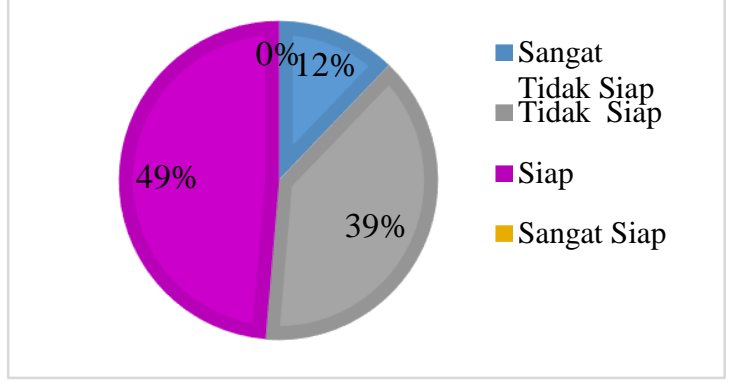

Gambar 6. Presentase Aspek Kesehatan Fisik dan Mental

\section{Aspek Bertanggung Jawab}

Dari hasil penelitian Tingkat kesiapan kerja berdasarkan aspek bertanggung jawab sebesar 5\% menyatakan sangat siap, 62\% menyatakan siap, 26\% menyatakan tidak siap dan $7 \%$ menyatakan sangat tidak siap.
Dengan perolehan presentase yang cukup tinggi saat meyatakan siap hal tersebut membuktikan para peserta didik dapat bertanggung jawab dengan beban kerja yang akan mereka hadapi nantinya ketika terjun ke dunia kerja.

Tabel 13. Deskripsi Statistik Aspek Bertanggung Jawab

\begin{tabular}{lc}
\hline \multicolumn{1}{c}{ Statistik } & Skor \\
\hline Skor ideal & 16 \\
Mean (rata-rata) & 13,7 \\
Median (nilai tengah) & 14 \\
Mode (modus) & 14 \\
Standard Deviation (standar deviasi) & 1,4 \\
Minimun (nilai terendah) & 9 \\
Maximum (nilai tertinggi) & 16 \\
\hline
\end{tabular}

Tabel 14. Kategori Penilaian Aspek Bertanggung Jawab

\begin{tabular}{|c|c|c|c|c|}
\hline No & Interval & Kategori & Frekuensi & Presentase \\
\hline 1 & $\begin{array}{c}X \geq \\
15,8 \\
13,7 \leq \\
X\end{array}$ & $\begin{array}{c}\text { Sangat } \\
\text { Siap }\end{array}$ & 4 & $5 \%$ \\
\hline 2 & $\begin{array}{c}15,8 \\
11,6 \leq\end{array}$ & Siap & 46 & $62 \%$ \\
\hline 3 & $\begin{array}{l}X< \\
13,7\end{array}$ & $\begin{array}{c}\text { Tidak } \\
\text { Siap } \\
\text { Sangat }\end{array}$ & 19 & $26 \%$ \\
\hline 4 & $\begin{array}{l}X< \\
11,6\end{array}$ & $\begin{array}{l}\text { Tidak } \\
\text { Siap }\end{array}$ & 5 & $7 \%$ \\
\hline \multicolumn{3}{|c|}{ Jumlah } & 74 & $100 \%$ \\
\hline
\end{tabular}

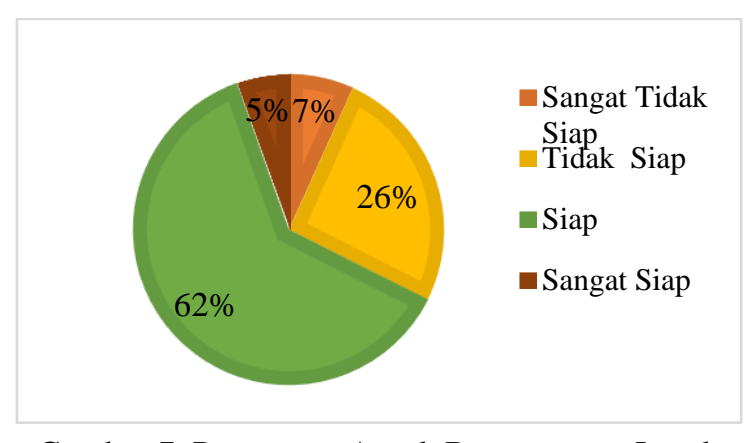

Gambar 7. Presentase Aspek Bertanggung Jawab

\section{Aspek Mampu Beradaptasi}

Hasil penelitian yang di dapat menunjukkan bahwa Tingkat kesiapan berdasarkan mampu beradaptasi sebesar $23 \%$ sangat siap, 23\% menyatakan siap, $36 \%$ menyatakan tidak siap dan $18 \%$ 
Tingkat Kesiapan... (Hanna/ hal. 75-84)

menyatakan sangat tidak siap. Presentase untuk aspek ini yang didapat memang sudah bisa dikatakan baik. Namun, peserta didik yang akan menghadapi dunia kerja harus tetap mampu beradaptasi karena keadaan di sekolah tidak sama dengan keadaan di dunia kerja. Meskipun cukup banyak yang berada pada kategori tidak siap, namun para peserta didik yang yang menjawab siap dan sangat siap cukup mendominasi.

Tabel 15. Deskripsi Statistik Aspek Mampu Beradaptasi

\begin{tabular}{lc}
\hline \multicolumn{1}{c}{ Statistik } & Skor \\
\hline Skor ideal & 16 \\
Mean (rata-rata) & 14,15 \\
Median (nilai tengah) & 14 \\
Mode (modus) & 15 \\
Standard Deviation (standar deviasi) & 1 \\
Minimun (nilai terendah) & 11 \\
Maximum (nilai tertinggi) & 16 \\
\hline
\end{tabular}

Tabel 16. Kategori Penilaian Aspek Mampu Beradaptasi

\begin{tabular}{|c|c|c|c|c|}
\hline No & Interval & Kategori & Frekuensi & Presentase \\
\hline & $X \geq$ & Sangat & & \\
\hline 1 & $\begin{array}{c}15,65 \\
14,15 \leq\end{array}$ & Siap & 17 & $23 \%$ \\
\hline & $\begin{array}{c}14,15 \leq \\
X<\end{array}$ & & & \\
\hline 3 & $\begin{array}{c}X< \\
14.15\end{array}$ & $\begin{array}{c}\text { Tidak } \\
\text { Sian }\end{array}$ & 27 & $36 \%$ \\
\hline 4 & $\begin{array}{c}X< \\
12,65\end{array}$ & $\begin{array}{c}\text { Sangat } \\
\text { Tidak } \\
\text { Siap }\end{array}$ & 13 & $18 \%$ \\
\hline \multicolumn{3}{|c|}{ Jumlah } & 74 & $100 \%$ \\
\hline
\end{tabular}

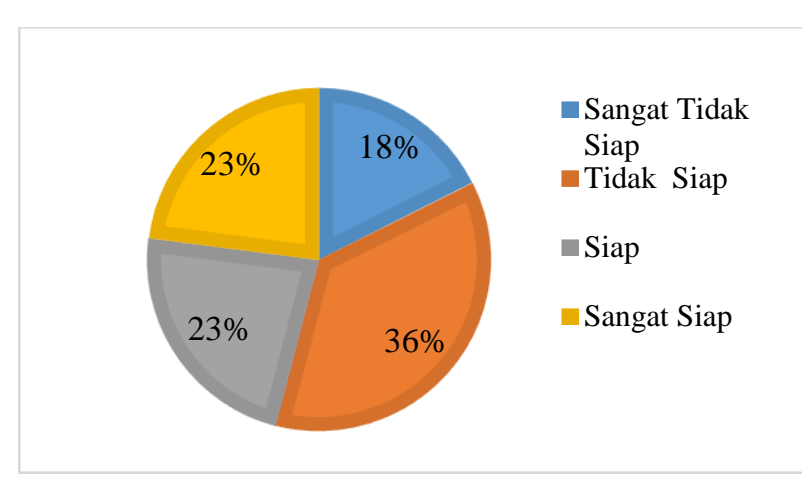

Gambar 8. Presentase Aspek Mampu Beradaptasi

\section{SIMPULAN}

Dari penelitian melalui analisis data yang telah dilakukan, maka dapat ditarik simpulan bahwa tingkat kesiapan peserta didik kompetensi keahlian desain pemodelan dan informasi bangunan SMK Negeri 2 Garut dalam menghadapi dunia kerja yaitu:

1. Gambaran umum tingkat kesiapan kerja berupa soft skill pada peserta didik desain pemodelan dan informasi bangunan SMK Negeri 2 Garut telah mencapai presentase yang cukup tinggi hal ini sejalan dengan tujuan dari SMK yang mendesain lulusannya agar dapat langsung bekerja di dunia kerja/dunia industri. Selain itu, tingkat kesiapan kerja para peserta didik ditunjang dari telah terlaksananya praktek kerja lapangan pada semester sebelumnya sehingga peserta didik memiliki pengalaman bekerja yang sesungguhnya.

2. Berdasarkan hasil penelitian dari aspekaspek yang digunakan yaitu:

a. Pada aspek tingkat kematangan didapatkan hasil perolehan nilai yang cukup tinggi hal ini didasarkan pada kematangan seseorang yang bertambah setiap harinya. Tingkat kematangan ini dikarenakan peserta didik telah melalui masalah-masalah dan menyelasaikannya.

b. Pada aspek memiliki pengalaman bekerja didapatkan hasil yang cukup tinggi dari peserta didik. Pengalaman bekerja yang diperoleh dari tempat dilaksanakannya Praktek Kerja Lapangan (PKL) membuat peserta didik mengaplikasikan ilmu yang 
diperoleh dari sekolah serta peserta didik juga dapat belajar dan mengetahui hal-hal baru dari dunia kerja. Pengalaman bekerja ini sangat diperlukan karena peserta didik setelah lulus tidak akan kaget lagi ketika dihadapkan dengan dunia kerja yang sesungguhnya.

c. Pada aspek memiliki pemikiran kritis peserta didik berada di kategori yang cukup tinggi. Pemikiran yang kritis merupakan soft skill yang sudah seharusnya dimiliki peserta didik dikarenakan terjun di dunia kerja akan menuntut mereka berfikiran cepat dan tepat ketika menyelesaikan masalah maupun tugas yang dihadapi. Pemikiran kritis dalam hal ini merupakan pemikiran yang mengandalkan logika karena di bidang konstruksi hal-hal yang dilaksanakan telah ada perhitungannya.

d. Pada aspek mampu berkomunikasi peserta didik sudah berada di kategori cukup tinggi, kemampuan berkomunikasi yang dimiliki ini dimaksudkan untuk memudahkan para peserta didik dalam berinteraksi. Baik berinteraksi dengan atasan, teman sebaya maupun pekerja lain yang berada di dunia kerja.

e. Pada aspek memiliki kesehatan fisik dan mental peserta didik dituntut untuk memiliki jasmani dan rohani yang kuat. Fisik dan mental yang sehat memudahkan kegiatan kerja di lapangan, kesehatan dua faktor ini harus dirawat agar membentuk profesionalitas ketika melakukan pekerjaan.

f. Pada aspek bertanggung jawab perolehan tingkat kesiapan yang didapat tinggi, hal ini diartikan bahwa peserta didik telah mampu melakukan dan dan menyelesaikan pekerjaan sebagaimana mestinya.

g. Pada aspek mampu beradaptasi peserta didik menyatakan ketidaksiapanny agak cukup tinggi. Mampu beradaptasi ketika di dunia kerja merupakan hal yang menunjang mereka untuk melakukan pekerjaan-pekerjaan selanjutnya.

\section{DAFTAR PUSTAKA}

Baititi, Ahmad Awaludin \& Munadi, S. (2014). Pengaruh Pengalaman Praktik, Prestasi Belajar Dasar Kejuruan Dan Dukungan Orang Tua Terhadap Kesiapan Kerja Peserta didik Smk. Jurnal Pendidikan Vokasi, 4(3), 164-180.

Dikmenjur. (2013). Pedoman Pelaksanaan Prakerin. Jakarta: Direktorat Pembinaan Sekolah Menengah Kejuruan, Depdiknas.

Fitriyanto, A. (2004). Ketidakpastian Memasuki Dunia Kerja karena Pendidikan. Jakarta: Rineka Cipta.

Hamalik, O. (2007). Pengembangan SDM Pelatihan Ketenagakerjaan Pendidikan Terpadu. Jakarta: PT. Bumi Aksara.

Jukianto. (2017). Pengaruh Prakerin Dan Peran Guru Pembimbing Terhadap 
Tingkat Kesiapan... (Hanna/ hal. 75-84)

Kesiapan Kerja Siswa Kelas XI Pemasaran Di SMK Negeri 1 Kota Jambi. (Skripsi). Universitas Jambi.

Mustifasari, A. K. (2015). Pengaruh Praktik Kerja Industri (Prakerin) Terhadap Kesiapan Kerja (Studi Pada Siswa Kelas XII Program Akuntansi Di SMK Nasional Pati Tahun Ajaran 2014/2015). (Skripsi). UNNES

Nurhaniah, N. (2013). Peranan Prestasi Belajar Dan PengetahuanTentang Dunia Kerja Terhadap Kesiapan Kerja Siswa SMK Negeri Jurusan Bangunan Di Kabupaten Sleman. (Jurnal Pendidikan Teknik Sipil dan Perencanaan). Retrieved from : https://core.ac.uk/download/pdf/1106 7256.pdf

Purwanto. (2009). Evaluasi Hasil Belajar. Surakarta: Pustaka Belajar.

Riduwan. (2009). Belajar Mudah Penelitian Untuk Guru-karyawan Dan Penelitian Pemula (cetakan ke-empat). Bandung: Alfa Beta.

Riduwan. (2010). Dasar- Dasar Statistika. Bandung: Alfa Beta

Siregar, S. (2011). Statistik Deskriptif untuk Penelitian dilengkapi perhitungan manual dan Aplikasi SPSS Versi 17. Cet 2. Jakarta: PT Rajagrafindo Persada.

Sudjana. (2002). Metode Statistika.

Bandung: Tarsito.

Sugihartono, D. (2007). Psikologi Pendidikan. Yogyakarta: UNY Pers.
Sugiyono. (2007). Statistika untuk Penelitian. Cet. XI. Bandung: CV. Alfabeta.

Sugiyono. (2012). Metode Penelitian Pendidikan. Bandung: CV. Alfabeta.

Sugiyono. (2014). Metode Penelitian Kuantitatif, Kualitatif dan $R \& D$. Bandung: CV. Alfabeta.

Sugiyono. (2016). Metode Penelitian Manajemen: Pendekatan Kuantitatif, Kualitatif, Kombinasi (Mix Methods), Penelitian Tindakan (Action Research), Penelitian Evaluasi. (Setiyawami, Ed.). Bandung: CV. Alfabeta.

Widoyoko, E. P. (2017). Teknik Penyusunan Instrumen Penelitian. Yogyakarta: Pustaka Pelajar. 